Valérie Baisnée, "Through the long corridor of distance": Space and Self in Contemporary New Zealand Women's Autobiographies

\title{
Patricia Neville
}

\section{(2) OpenEdition}

\section{Journals}

Electronic version

URL: https://journals.openedition.org/ces/5629

DOI: $10.4000 /$ ces.5629

ISSN: 2534-6695

Publisher

SEPC (Société d'études des pays du Commonwealth)

\section{Printed version}

Date of publication: 1 April 2016

Number of pages: 133-134

ISSN: 2270-0633

Electronic reference

Patricia Neville, "Valérie Baisnée, "Through the long corridor of distance": Space and Self in Contemporary New Zealand Women's Autobiographies", Commonwealth Essays and Studies [Online], 38.2 | 2016, Online since 06 April 2021, connection on 01 July 2021. URL: http://journals.openedition.org/ces/5629; DOI: https://doi.org/10.4000/ces.5629

This text was automatically generated on 1 July 2021.

\section{$(1) \Theta \Theta$}

Commonwealth Essays and Studies is licensed under a Licence Creative Commons Attribution - Pas d'Utilisation Commerciale - Pas de Modification 4.0 International. 


\title{
Valérie Baisnée, "Through the long corridor of distance": Space and Self in Contemporary New Zealand Women's Autobiographies
}

\author{
Patricia Neville
}

\section{REFERENCES}

Valérie Baisnée. "Through the long corridor of distance": Space and Self in Contemporary New Zealand Women's Autobiographies. Amsterdam \& New York: Rodopi, Cross/Cultures 175, 2014. 156 p. ISBN: 978-9-04203-868-4. €42.00, \$54.00

\footnotetext{
"Writing about one's past involves both invention and exorcisms: finding what was lost and would

have been permanently lost otherwise; and freeing oneself of the burden of it, when it is a burden." Charles Brasch, Journals, 1968.
}

In her introduction to her study of autobiographies of New Zealand women, Valérie Baisnée reminds us that Charles Brasch, founder and editor of Landfall, New Zealand's pre-eminent literary quarterly, encouraged autobiographical writing with his "Beginnings" series in the mid 1960s. He invited a variety of New Zealand writers to reflect on their roots, having long regarded autobiography as a major form of imaginative writing, as the quotation from his Journals entry shows. Janet Frame and Ruth Dallas both contributed accounts of their "Beginnings," and subsequently went on to write full-length autobiographies. Autobiography has frequently been used by marginalised and minority voices as a way of making themselves heard in dominant cultures, and Baisnée's study considers the work of Frame, Dallas and other New Zealand women writers who contributed in varying ways to the same genre: Sylvia Ashton-Warner, Lauris Edmond, Ruth Parks, Fiona Kidman and Barbara Anderson - 
with brief mentions also of Keri Hulme, Marilyn Duckworth, Robin Hyde and Patricia Grace - women who make their voices heard in a male-dominated New Zealand society, and one isolated by its geography and the vast ocean.

Baisnée has chosen to focus on the work of women of different generations, all writing in the 1970s, a time of increased cultural awareness in New Zealand and of the rise of feminist movements around the English-speaking world, but whose autobiographies cover a much broader period of time. Some of these women were always involved with the literary world, writing prose and poetry for publication from an early age; others, notably Lauris Edmond, felt themselves primarily wives and mothers, celebrating motherhood while regretting the loss of self-definition, concealing their writing until much later in life, conscious of their restricted freedom and lacking "a room of one's own." Among these women there are varying concepts of truth and memory, Janet Frame famously referring to autobiography as "found fiction," refusing to be bound by the conventions of the genre, and refusing to conform to the female stereotype; Lauris Edmond, by contrast, seeing her writing as an escape from the domestic sphere. Baisnée is attuned to the use of poetic expression in these autobiographies, and notes that all these women wrote poetry as well as prose - Ruth Dallas includes her own poems in hers. In her comment on Frame's "weakness for metaphors" (43), Baisnée appears to be attributing the criticism to Charles Brasch, although the phrase comes from Owen Leeming's lukewarm review of Scented Gardens for the Blind (Landfall 68, Dec. 1963). Frame comments on this criticism in the letter to Brasch which Baisnée quotes, revealing, as Baisnée argues, Frame's "investment in tropes without which the communication of her experience would be impossible." Baisnée is keenly aware of the importance of metaphor in autobiographical writing, organising her study into chapters based on a variety of characteristic tropes: "Thresholds," "Homes," "Displaced Bodies, Disembodied Texts," "Landscapes," and "Itineraries." She also identifies the blurring of the border between fiction and truth, and the selectivity of memory distorted by time or trauma.

3 The male-dominated literary scene - Landfall editor and poet Charles Brasch, pub-lisher and poet Dennis Glover, poets Allen Curnow and James Baxter, novelist and short storywriter Frank Sargeson - whether benignly patronising or dismissive of women writers, expected New Zealand authors to write about the New Zealand landscape. Baisnée demonstrates that landscape and a sense of geographical place was equally important to these women writers, illustrating her argument with particular reference to Fiona Kidman and Ruth Dallas. Kidman's attachment was to the Kerikeri of her childhood, Dallas uses her poetry to connect with her surroundings and in Curved Horizon recounts her relationship with the landscape, and Janet Frame felt a sense of belonging in the "land of the mythmakers." There is an English dialect expression, "hefted to the land," drawn from the language of migrating Norsemen and Saxons who settled in England, which expresses a sense of connection with the soil beneath one's feet, a spiritual association, a rootedness, through which migrants form a relationship with a new homeland and establish a new identity - an ancient expression for an ancient concept. Baisnée adopts Bachelard's "topophilia" to convey a similar range of meaning, for New Zealanders' emerging sense of identification with the land, but more eloquently expressed in Baisnée's quotation of a line from a poem by Ruth Dallas: "But now I know it is I who exist in the land." 
Baisnée draws on the transcultural work of philosophers, linguists and geographers in her discussion of "space" and "place" as concepts in relation to mobility and migration. Feelings of displacement expressed by Janet Frame, Marilyn Duckworth, Sylvia AshtonWarner, and Robin Hyde, for example, of being rejected or under-valued by one's own country, led some of these women writers to find temporary or permanent homes elsewhere: in the USA or in Britain if they had the means and freedom to travel, or in Australia. For women, home is often a prison as much as a sanctuary, trapped by both the weight of social expectation and by love of family. Baisnée has provided a valuable analysis and comparison of the variety of ways in which New Zealand women writers have used autobiography as a means of imaginative escape into another world, though her book is ill-served by inaccuracies in the index. Baisnée examines ways New Zealand women have found of making their voices heard, reclaiming ownership of their own stories through poetic imagination. She is aware that these writers cannot tell everything - "parts of our stories can never reach consciousnesses" - but that in their autobiographies they have written an imaginative truth.

\section{AUTHORS}

\section{PATRICIA NEVILLE}

Patricia NEVILLE is a recently retired English teacher engaged in researching a doctoral thesis with the Open University in the U.K., focussing on the novels of Janet Frame. Earlier this year she made a month-long research visit to the Hocken Archives Collection of the University of Otago, Dunedin. She contributed to the Janet Frame Colloquium, Janet Frame: Ten Years On, in London in November 2013, and has written a review of Janet Frame: In Her Own Words for the New Zealand Studies Network website. 